\title{
Is Hypertension a Disorder of Volume Control? What Is the Evidence?
}

\author{
Graeme Mindel Aubrey R. Morrison \\ Department of Medicine, Washington University School of Medicine, St. Louis, Mo., USA
}

\section{Key Words}

Genetics of hypertension $\cdot \mathrm{Na}^{+}$homeostasis $\cdot \mathrm{Na}^{+}$

transporters $\cdot$ Intrauterine imprinting $\cdot$ Renal function

\begin{abstract}
The etiological factors responsible for the hypertensive phenotype are complex and several experimental and clinical observations point to a major role of the kidney as being responsible. Genetic studies of uncommon diseases which express monogenetic inheritance all have in common a dysregulation of $\mathrm{Na}^{+}$balance and volume expansion. Furthermore, epidemiological data suggest an increased incidence of hypertension in communities with high excretory rates of $\mathrm{Na}^{+}$. Experimental data also suggest that low birth weight is associated with an increase in the frequency of hypertension later in life and raises the possibility that intrauterine imprinting may contribute to the expression of the phenotype. Upregulation of the $\mathrm{Na}^{+} / \mathrm{K}^{+} / 2 \mathrm{Cl}^{-}$and thiazide-sensitive transporters in low birth weight animals may provide the physiological basis for these observations. In addition, low birth weight is associated with a decrease in nephron number. Therefore, low nephron number may induce adaptive changes in utero which influence volume homeostasis later in life and subtle gain of function mutations in one or more of these transporters may unmask
\end{abstract}

defects in volume homeostasis with increasing salt intake. Finally, the high prevalence of hypertension in functionally anephric patience seems to respond to sustained maintenance of 'dry weight' through ultrafiltration.

Copyright (C) 2005 S. Karger AG, Basel

Worldwide, elevation of blood pressure is a common trait and in the USA affects about $15-20 \%$ of the adult population. It contributes directly or indirectly to about 220,000 deaths annually from stroke, myocardial infarction and renal failure [1]. The definition of hypertension has evolved over several decades away from arbitrary values towards an emphasis on the levels of blood pressure that are associated with vascular damage and increased cardiovascular morbidity and mortality. This generates an enormous problem that physicians, healthcare providers and patients must grapple with, since individuals aged 55-65 have a lifetime probability of $90 \%$ for the development of hypertension [2] as currently defined.

In the mid 20th century, two prevailing views on essential hypertension existed. The first championed by Lord Platt suggested that hypertension resulted from a defect in a gene or genes each of which were sufficient to produce the phenotype, resulting in two populations, those who are normotensive or hypertensive. The second prevailing view was that of Sir Thomas Pickering, who

\section{KARGER \\ Fax +4161306 1234 E-Mailkarger@karger.ch} www.karger.com
(C) 2005 S. Karger AG, Basel $1660-2137 / 05 / 1013-0063 \$ 22.00 / 0$

Accessible online at: www.karger.com/nep
Aubrey R. Morrison, MD

Department of Medicine, Renal Division Box 8126

Washington University School of Medicine

St Louis, MO 63110 (USA)

Tel. +1 314 4548495, E-Mail morrison@pcg.wustl.edu 
Fig. 1. Model of pathogenesis of hyperten-

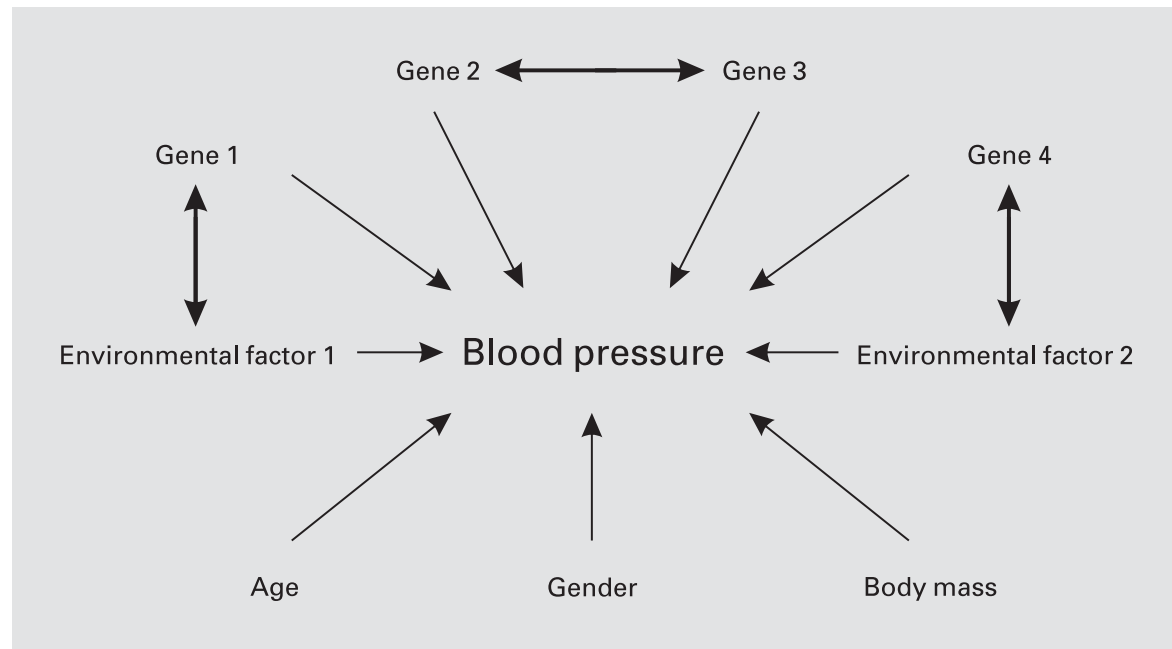
sion.

suggested that hypertension resulted from the cumulative effect of several dysregulated genes, which individually were not sufficient to result in the hypertensive phenotype. As such, blood pressure was a continuum with hypertension being one of the extremes of blood pressure variation in the community. This latter view has received some support from a large body of experimental work which has led to a hypothesis championed by Oliver Smithies who suggests that 'essential hypertension results from contributions of genetic variation that are not the same in all affected persons and that individually may not cause sufficient deviation from normality to be harmful'. This has led to the concept of multifactorial determinants of blood pressure in which genetics and other epigenetic factors such as gender, body mass, age and environment all contribute to the observed phenotype and this concept is illustrated in figure 1.

Currently the majority of hypertension is believed to fall into the category of disorders with complex inheritance and as such presents several challenges to the geneticist. A complimentary approach to the large body of physiologic information is the identification of genetic factors contributing to the pathogenesis of hypertension. If key mutations can be found, they should provide a rational springboard from which the pathophysiology of hypertension can be understood, especially since evidence from epidemiology, twin studies and adoptive studies, suggests a role for heredity in $25-40 \%$ of human hypertension [3]. The latter approach has been exploited efficiently by Lifton et al. [4] who have identified genes which influence blood pressure variation at the low and high end of the spectrum. What is important for this discussion is that, without exception, the diseases whose molecular pathogenesis has been defined by this approach, all directly or indirectly affect salt balance and hence influence the status of the extracellular volume (ECV) (table 1).

The control of ECV is not completely understood, nevertheless several physiological systems have been identified which affect sodium handling by the kidney. Indeed the kidney is the organ which assumes primacy in the efferent arm of the physiological control homeostatic mechanism. One of the best studied systems in this regard is the renin/angiotensin/aldosterone axis. This axis is comprised of angiotensinogen $(A G T)$, which circulates in plasma where it is the substrate for proteolytic cleavage by renin, produced in the juxtaglomerular apparatus of the mammalian kidney. AGT circulates in plasma at concentrations close to the $\mathrm{K}_{\mathrm{m}}$ for renin, thus changes in the level of $A G T$ will produce significant changes in the levels of circulating angiotensin $\mathrm{I}(\mathrm{AI})$, the product of cleavage of $A G T$ by renin. AI is subsequently cleaved to angiotensin II (AII) by angiotensin-converting enzyme (ACE) in the lung and other tissues, increases vascular smooth muscle tone, and enhances the secretion of aldosterone from the adrenal glomerulosa through the AT1 receptor. Aldosterone binds to the mineralocorticoid receptor in the distal convoluted tubule to promote $\mathrm{Na}^{+}$reabsorption through genomic and non-genomic mechanisms. Several mutations in various key players along the renin/angiotensin/aldosterone axis have been identified. These mutations have been associated with an elevated blood pressure and have in common $\mathrm{Na}^{+}$retention as the physiologic root of this observed phenotype. 
Table 1. Mutations affecting circulating mineralocorticoid hormones

\begin{tabular}{|c|c|c|c|}
\hline Disorder & Genetics & Pathogenesis & Clinical features \\
\hline $\begin{array}{l}\text { Polymorphisms in the } \\
\text { human angiotensinogen } \\
(A G T) \text { gene }\end{array}$ & & $\begin{array}{l}\text { Increased promoter activity } \rightarrow \text { increased circu- } \\
\text { lating AGT } \rightarrow \mathrm{Na}^{+} \text {retention and hypertension }\end{array}$ & $\begin{array}{l}\text { Only } 2 \text { kindreds identified. Effect may } \\
\text { be modest and the physiologic impor- } \\
\text { tance is not fully understood }\end{array}$ \\
\hline $\begin{array}{l}\text { Glucocorticoid } \\
\text { remediable } \\
\text { aldosteronism }\end{array}$ & $\begin{array}{l}\text { Autosomal } \\
\text { dominant } \\
\text { with complete } \\
\text { penetrance }\end{array}$ & $\begin{array}{l}\text { Unequal crossing over between aldosterone } \\
\text { synthase and } 11 \beta \text {-hydroxylase } \rightarrow \text { chimeric } \\
\text { gene expressed in the zona fasciculata encoding } \\
\text { aldosterone synthase under the control of ACTH }\end{array}$ & $\begin{array}{l}\text { Excess mineralocorticoid secretion } \\
\text { with normal to elevated aldosterone } \\
\text { levels despite suppressed plasma renin } \\
\text { activity. Variable hypokalemic meta- } \\
\text { bolic alkalosis. Suppression of aldo- } \\
\text { sterone secretion by exogenous } \\
\text { administration of glucocorticoids }\end{array}$ \\
\hline $\begin{array}{l}\text { Syndrome of } \\
\text { apparent } \\
\text { mineralocorticoid } \\
\text { excess }\end{array}$ & $\begin{array}{l}\text { Autosomal } \\
\text { recessive }\end{array}$ & $\begin{array}{l}\text { Homozygous loss of function of } 11 \beta \text {-hydroxy- } \\
\text { steroid dehydrogenase type II gene } \rightarrow \text { cortisol } \\
\text { exerting a mineralocorticoid effect with } \mathrm{Na}^{+} \\
\text {retention, volume expansion and hypertension }\end{array}$ & $\begin{array}{l}\text { Early onset hypertension. Hypokalemic } \\
\text { metabolic alkalosis. Low plasma renin } \\
\text { and aldosterone levels }\end{array}$ \\
\hline
\end{tabular}

Mutations in the mineralocorticoid receptor

Geller's syndrome Autosomal Missense mutation in the minerlacorticoid dominant receptor $\mathrm{S} 810 \mathrm{R} \rightarrow$ activation of the mineralcorticoid receptor by steroids lacking

21-hydroxyl groups such as progesterone

Early onset hypertension prior to the age of 20. Accelerated hypertension during pregnancy with suppression of the renin-angiotensin system

Mutations in renal ionic channels and transporters

\begin{tabular}{lll}
\hline Liddle syndrome & $\begin{array}{l}\text { Autosomal } \\
\text { dominant }\end{array}$ & $\begin{array}{l}\text { Enhanced activity of the epithelial sodium } \\
\text { channel (ENAC) } \rightarrow \text { increased } \mathrm{Na}^{+} \text {transport } \\
\end{array}$ \\
& $\rightarrow$ volume expansion and hypertension
\end{tabular}

Onset of hypertension in adolescents and young adults. Low renin and aldosterone. Hypokalemic metabolic alkalosis

\begin{tabular}{ll}
\hline $\begin{array}{l}\text { Gordon's syndrome } \\
\text { (pseudohypoaldoste- }\end{array}$ & $\begin{array}{l}\text { Autosomal } \\
\text { dominant }\end{array}$ \\
ronism type II) &
\end{tabular}

Mutations in the WNK 1 and 4 genes $\rightarrow$ increased expression of the thiazide-sensitive transporter on the apical membrane of the DCT $\rightarrow$ enhanced $\mathrm{NaCl}$ reabsorption with volume expansion and hypertension

Mutations in the $\alpha$-adducin gene
Adducin is a cytoskeletal protein. Expression of the mutant protein $\rightarrow$ alteration in the actin polymerization $\rightarrow$ increased $\mathrm{Na}^{+}$reabsorption through the kidney
Hyperkalemia. Hyperchloremic nonanion gap metabolic acidosis. Low to normal plasma renin activity and aldosterone

Homozygous mutations have been expressed as a form of salt-sensitive hypertension in an Italian kindred

\section{Mutations in AGT}

Two kindreds have been identified, one in Salt Lake City and the other in Paris, in which elevation of blood pressure is linked to polymorphisms in the human $A G T$ gene $[5,6]$. The M235T variant has been associated with another mutation in nucleotide -6 from the initiation site of transcription [7] and which results in increased promoter activity in a heterologous expression system. This mutation would therefore be expected to result in an increase in circulating $A G T$ and based on the discussion above would result in $\mathrm{Na}^{+}$retention and increased BP. This interpretation has gained support from experiments in mice where one through four copies of the $A G T$ gene were sequentially added on a null background [8]. With each additional copy of the $A G T$ gene the blood pressure was proportionally elevated confirming that the levels of circulating $A G T$ could influence BP in an intact animal. 


\section{Glucocorticoid Remediable Aldosteronism}

Glucocorticoid remediable aldosteronism is an autosomal dominant trait, producing hypertension of early onset and associated with suppressed plasma renin activity [9]. It arises as a consequence of a gene duplication consisting of an unequal crossing over between aldosterone synthase and steroid $11 \beta$-hydroxylase. This results in the presence of a chimeric gene ectopically expressed in the zona fasiculata, which encodes aldosterone synthase and whose expression is under the control of ACTH $[4,10]$. This results in excess mineralocorticoid secretion, $\mathrm{Na}^{+}$retention, volume expansion and hypertension.

\section{Syndrome of Apparent Mineralocorticoid Excess}

This is an autosomal recessive disease whose clinical features are onset of early hypertension, hypokalemic metabolic alkalosis, suppressed plasma renin and absence of circulating aldosterone. This disease is a consequence of homozygous loss-of-function in the $11 \beta$-hydroxysteroid dehydrogenase type- 2 gene in the distal renal tubule [11]. The absence of this enzyme allows cortisol to act as a mineralocorticoid to promote $\mathrm{Na}^{+}$retention, volume expansion and hypertension.

\section{Mutations in the Mineralocorticoid Receptor}

Recently a kindred was identified with an activating mutation of the mineralocorticoid receptor which demonstrated autosomal dominant transmission [12]. This resulted from a missense mutation, S810R, and all carriers of the mutation developed hypertension before age 20 . Another feature of the affected kindred was that, while wild-type receptor was not activated by progesterone, the mutant receptor was fully activated by this steroid, thus providing the basis for an accelerated hypertension in affected females with pregnancy. As with the above genetic abnormalities in the renin/angiotensin/aldosterone axis, the physiology of a constitutively active mineralocorticoid receptor would cause excessive $\mathrm{Na}^{+}$retention, volume expansion and hypertension.

Mutations in the renin/angiotensin/aldosterone axis are uncommon disorders which lead to elevated blood pressure associated with $\mathrm{Na}^{+}$retention and volume expansion. Nevertheless, the evidence placing the kidney as a major player in the pathogenesis of salt-sensitive hyper- tension is very compelling. Experimental evidence in rats from Dahl et al. [13] and others [14] has demonstrated through cross-transplantation experiments that the defect which allowed the expression of the phenotype resides in the kidney. There is also clinical evidence that suggests that hypertension in African Americans could be cured with transplantation of kidneys from normotensive donors [15]. These observations are supported by epidemiological data showing a strong correlation between the frequency of hypertension in large populations and the levels of urinary $\mathrm{Na}^{+}$excretion (a surrogate for $\mathrm{Na}^{+}$intake) [16]. Finally, there is evidence for a gene influencing blood pressure on chromosome 17, obtained by genome wide scans of subjects from the Framingham Study [17]. This QTL is of particular interest because it is syntenic with a QTL on chromosome 10 in rats $[18,19]$, linked to hypertension in several studies of spontaneously hypertensive rats, and syntenic to a QTL on chromosome 11 in the mouse [20], linked to salt sensitivity in a hypertensive mouse strain.

The kidney is the major organ charged with the defense of the ECV and does this through signals which influence a number of channels and transporters along the length of the nephron. The kidney excretes under normal conditions and with a full complement of nephrons, $0.5-1.0 \%$ of the filtered load of sodium. It accomplishes this fine regulation through a phenomenon known as glomerulotubular balance and the appropriate level of coordinated $\mathrm{Na}^{+}$reabsorption. This delicate balance can be disrupted by a malfunction directly or indirectly, from loss-of-function or gain-of-function of one or more transport proteins or channels that orchestrate this homeostatic function.

Epidemiological studies have suggested a correlation between hypertension late in life and intrauterine growth retardation [21-24]. The correlation is with low birth weight, rather than prematurity, and suggests that the in utero environment is responsible for imprinting and programming of blood pressure. Compared to white Americans, hypertension in African Americans is more prevalent, occurs earlier in life, is more severe and is more often associated with end-organ damage [25]. National Health and Nutrition Examination Survey (NHANES) data, looking at trends in prevalence, awareness, treatment and control of hypertension in the USA, indicated that nonHispanic black race/ethnicity was independently associated with increased rates of hypertension [26]. African American infants weigh on average 200-300 g less at birth than do European American infants resulting in a two- to threefold higher risk for low birth weight and very low birth weight among black infants compared with 
white infants. Although infant mortality has decreased among all races during the past two decades, the overall black-white gap for infant mortality has widened. The basis for this disparity is unclear but numerous factors have been associated with increased risk for having a low birth weight infant including socioeconomic status, the age and health of the mother, prenatal care and maternal anthropometrics [27]. There are both animal and human data linking low birth weight with reduced nephron mass. In an animal study, Leroy and co-workers [28] showed that full-term rat pups with intrauterine growth retardation had lower kidney weights and a reduced number of glomeruli than pups in the normal weight group. It is therefore a possibility that low birth weight may be a significant contributing factor to the observed racial differences in hypertension severity and cardiovascular outcomes. Furthermore, the higher salt intake in the African American population may further exacerbate this disparity.

In an experimental model of intrauterine growth retardation, Manning et al. [29] demonstrated upregulation of the $\mathrm{Na}^{+} / \mathrm{K}^{+} / 2 \mathrm{Cl}^{-}$and $\mathrm{Na}^{+} / \mathrm{Cl}^{-}$electroneutral transporters in the mammalian nephron. If the function of these two transporters correlated with the levels of their expression, they would be expected to enhance $\mathrm{Na}^{+}$reabsorption and thus volume expansion. It should not be surprising therefore if gain-of-function mutations were identified in transporters along the mammalian nephron, they could result in an increase in ECV and hypertension. Such mutations have been identified.

\section{Liddle's Syndrome}

Liddle's syndrome is characterized by hypertension with its onset in early childhood and associated with hypokalemic alkalosis. The molecular defect in these patients is a result of mutations in either the $\mathrm{C}$-terminus of the $\beta$ or $\gamma$ subunits of the epithelial sodium channel (ENaC) [30, 31]. This C-terminus carries a PPPXY motif which interacts with the WW motifs of Nedd4-1 and -2, proteins that interact with the ubiquitin ligase and are responsible for recycling of $\beta$ and $\gamma$ subunits in clathrincoated pits [32-34]. This mutation increases the number of functioning channels in the apical membrane of the distal nephron and enhances $\mathrm{Na}^{+}$reabsorption resulting in volume expansion.

Is Hypertension a Disorder of Volume Control?

\section{Pseudohypoaldosteronism Type II (Gordon's Syndrome)}

This is an autosomal dominant disorder, genes for which have been mapped in different families to chromosome 17,1 or $12[35,36]$. The hypertension has been attributed to renal $\mathrm{Na}^{+}$retention. Mutations in WNK1 and 4 genes have been identified in some families and appear to be the molecular basis for the observed phenotype [37] in some of the families but not all. It is interesting to note that the defect in WNK1 families is associated with a fivefold increase in kinase expression (gain of function) while the defect in WNK4 is associated with a loss-offunction of the kinase with increased expression of the thiazide-sensitive transporter on the apical membrane of the DCT.

\section{Mutations in the $\alpha$-Adducin Gene}

Identification of a candidate gene in the Milan hypertensive rat which encoded the $\alpha$ and $\beta$ isoforms of adducing [38] led to the identification of families which expressed this mutation and in whom the homozygous mutation was expressed as salt-sensitive hypertension [39]. The point mutations identified were in $\alpha(\mathrm{F} 316 \mathrm{Y})$ and $\beta(\mathrm{Q} 529 \mathrm{R})$ isoforms of adducin in the rat [38] and in the human $\alpha$-adducin, the SNP identified a Gly406Trp on chromosome 4 as being associated with salt-sensitive hypertension [39]. The heterodimer of $\alpha$ - and $\beta$-adducin interacts with F-actin and spectrin $[38,40]$ and in vitro experiments have demonstrated that the expression of the mutant protein is associated with a significant increase in the expression of $\mathrm{Na}^{+} \mathrm{K}^{+}$-ATPase in renal epithelia and which is associated with an increase in $\mathrm{V}_{\max }$ of the transporter. This would be expected to lower the $\mathrm{Na}^{+}$activity in transporting epithelia with an increase in secondary active transport through the $\mathrm{Na}^{+} / \mathrm{H}^{+}$exchanger and will therefore account for the enhanced $\mathrm{Na}^{+} / \mathrm{Li}^{+}$countertransport seen in these families. This mutation would therefore increase $\mathrm{Na}^{+}$reabsorption, resulting in volume expansion.

Based on a large body of work throughout his scientific career, Guyton [41, 42] has demonstrated that there is a pressure natriuresis system in the mammalian kidney which is activated within hours to days to defend the level of ECV to 'normal' limits. This system is believed to have infinite gain and is the only system endowed with the ability to completely restore ECV to normal when deviations occur. Small changes in ECV can have significant

Nephron Physiol 2005;101:p63-p71 p67 
changes in blood pressure [41], and as a result it is conceivable that polymorphisms in the multiple channels and transporters along the nephron which produce subtle alterations in function could be unmasked with a high $\mathrm{Na}^{+}$intake. This could be the underlying basis for the increased frequency of hypertension in communities which have increased rates of $\mathrm{Na}^{+}$ingestion. The observations in Gordon's syndrome also underscore the possibility that hypertension may result from mutations in proteins which alter the function of the transporters and channels, thus providing the potential for mutations in several renal proteins to influence $\mathrm{Na}^{+}$handling by the kidney through direct and indirect mechanisms.

We have already pointed out that there are a number of genetic conditions that are associated with alterations in sodium transport in the tubules. Others have reviewed in detail the numerous possible mechanisms of acquired renal injury as a cause of salt-sensitive hypertension and the pathways through which this is achieved [43].

An emerging concept is that congenital reduction in the number of nephrons may limit the filtration of sodium, resulting in sodium retention and an elevation of blood pressure [44]. This has been alluded to previously by Guyton and co-workers [45] in the analysis of the kidney's role in different types of hypertension. Under normal conditions, equilibrium is achieved at an arterial pressure of $100 \mathrm{~mm} \mathrm{Hg}$, i.e., intake and output of water and salt are matched. Where there has been loss of renal mass, equilibrium is achieved at a higher arterial pressure. Furthermore, when the intake of salt and water are increased, the diminished renal mass kidneys demonstrate a considerably greater increase in the blood pressure than the normal kidney. This may suggest a reduced capacity to filter or excrete the sodium load - in essence a rightward shift in the pressure natriuresis curve. It is also worth mentioning the effect of non-steroidal anti-inflammatory drugs (NSAIDs). Inhibition of intrarenal prostaglandins may result in intrarenal vasoconstriction with sodium retention and development of hypertension. In addition, cyclooxygenase-2-derived prostaglandin $\mathrm{E}_{2}$ is found in the thick ascending limb of the loop of Henle where it inhibits sodium reabsorption. NSAID-induced inhibition of prostaglandin $E_{2}$ can therefore result in salt and water retention. NSAIDs and cyclooxygenase inhibitors vary in their effect on blood pressure but this effect is most pronounced in patients with hypertension, impaired renal function and in individuals who demonstrate salt sensitivity.

In our aging population, because of the higher incidence of arthritic related symptoms, the use of NSAIDs and COX2i may take on a greater significance. These individuals have a reduced renal mass and a greater tendency to salt sensitivity and so the use of these agents may be associated with a greater degree of incident hypertension.It is clear that blood pressure control is a major problem in functionally anephric individuals. If one looks at the distribution of both systolic and diastolic blood pressure measurements in the dialysis population, then approximately $80 \%$ of dialysis patients will have hypertension as defined by the JNC VII criteria with a systolic blood pressure $>140 \mathrm{~mm} \mathrm{Hg}$ and a diastolic blood pressure $>90 \mathrm{~mm} \mathrm{Hg}$ [46]. There are a variety of reasons postulated for the development of hypertension in the dialysis patient. These include: volume loss, increased vasopressor activity or decreased vasodilator activity, and hormones including parathyroid hormone and erythropoietin. Despite all of these possibilities it is clear that volume reduction is associated with improved blood pressure control. This is best demonstrated in the Tassin study group in France in which patients received longer periods of dialysis ( $24 \mathrm{~h} /$ week) with greater degrees of ultrafiltration. Virtually none of these patients required antihypertensive medication because of improved ultrafiltration [47]. It is interesting to note that this same group observed a phenomenon, which they have termed the "lag phenomenon'. This describes a set of circumstances in which, despite reduction of the ECV, significant changes in the mean arterial pressure were only seen weeks to months later (fig. 2). They postulated that this may occur as a result of a reversal in the sequence of hemodynamic modifications described by Guyton when patients with chronic kidney disease are exposed to a saline load [48]. Based on Guyton's principles, it is probable that improved ECV control in dialysis patients, achieved by greater degrees of ultrafiltration, will eventually result in a reduction in the peripheral vascular resistance. Once the dialysis patient reaches his or her true 'dry weight', the reduction in the peripheral vascular resistance is associated with the observed improvement in the mean arterial pressure, a process which may take several weeks to months.

Recently, Keller and co-workers [49] demonstrated that the number of glomeruli is lower in the kidneys of patients with hypertension than in the kidneys of matched normotensive controls. Whether the cause of this reduced nephron mass is genetic or epigenetic is unknown. Equally plausible is that the resulting reduced nephron number could have been due to intrauterine events as discussed earlier and hypertension expressed as a consequence of the reduced nephron number. Experimental data in rats 
Fig. 2. Pre-dialysis blood pressure and postdialysis weight in 712 Tassin study patients. Anti-HT = Antihypertensive therapy [from 48, with permission].

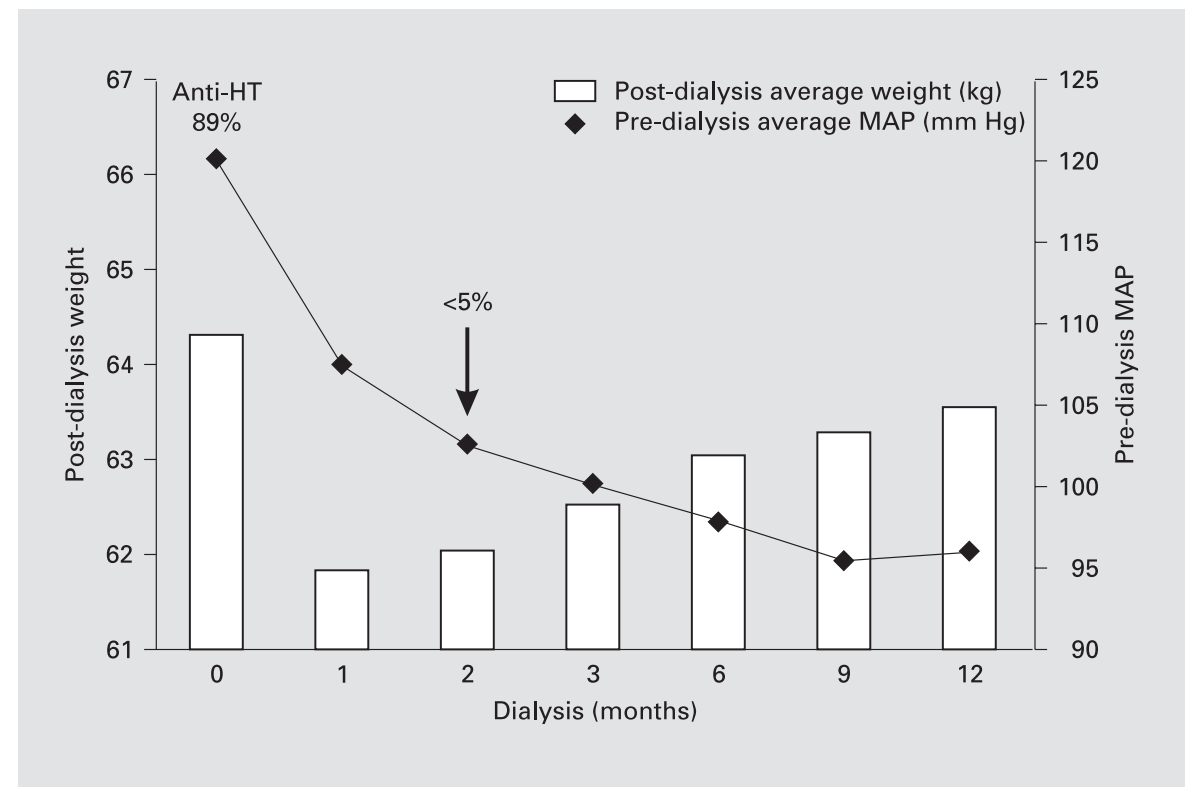

$[50,51]$ and sheep [52] suggest that uninephrectomy predisposes these animals to the development of hypertension later in life. There is a suggestion that removal of a kidney also predisposes patients to the development of hypertension later in life and that males are more likely to exhibit an elevated blood pressure [53-55]. However, there is a significant body of accumulating data in the donors of kidneys for transplantation that the uncomplicated reduction of $50 \%$ of nephrons produced by donor nephrectomy is not associated with an increased incidence of hypertension nor increased rates of ESRD [5658]. This occurs in spite of hyperfiltration in the remaining solitary kidney. This suggests, first, that a simple reduction of up to $50 \%$ of the complement of nephrons in humans is insufficient to produce hypertension in spite of the physiological adaptations, and second, that the reduction of nephron number in the neonatal period which is associated with hypertension later in life must occur as a result of other factors present in the developing kidney in which nephron 'plasticity' allows for enhanced expression of transporters, which is not seen in the fully differentiated adult kidney.

It is clear that an elevated blood pressure can induce functional adaptive changes in the resistance vessels in the arterial tree. However, equally well documented is the observation of structural changes in the vessels which can eventually lead to end-organ damage which may not be reversible. This may therefore account for the inability to reverse blood pressure to normal with pharmacological reversal of the physiological derangements observed in some of the genetic syndromes described above and makes a powerful argument for aggressive blood pressure control early in the natural history of this very important disease. The concept proposed in this review will be further supported if new hypertensive genes express themselves through a dysregulation of $\mathrm{Na}^{+}$homeostasis and volume control. 


\section{References}

- 1 Mosterd A, D'Agostino RB F, Silbershatz H, et al: Trends in the prevalence of hypertension, antihypertensive therapy, and left ventricular hypertrophy from 1950 to 1989 . N Engl J Med 1999;340:1221-1227.

-2 Vasan RS, Beiser A, Seshadri S, et al: Residual lifetime risk for developing hypertension in middle-aged women and men: The Framingham Heart Study. JAMA 2002;287:10031010.

>3 Karet FE, Lifton RP: Mutations contributing to human blood pressure variation. Recent Prog Horm Res 1997;52:263-276.

-4 Lifton RP, Gharavi AG, Geller DS: Molecular mechanisms of human hypertension. Cell 2001;104:545-556.

5 Jeunemaitre X, Charru A, Chatellier G, et al: M235T variant of the human angiotensinogen gene in unselected hypertensive patients. J Hypertens 1993;11(suppl 5):S80-S81.

-6 Jeunemaitre X, Soubrier F, Kotelevtsev YV, et al: Molecular basis of human hypertension: Role of angiotensinogen. Cell 1992;71:169180.

7 Inoue I, Nakajima T, Williams CS, et al: A nucleotide substitution in the promoter of human angiotensinogen is associated with essential hypertension and affects basal transcription in vitro. J Clin Invest 1997;99:1786-1797.

-8 Kim H, Krege JH, Kluckman KD, et al: Genetic control of blood pressure and the angiotensinogen locus. Proc Natl Acad Sci USA 1995;92:2735-2739.

-9 Rich GM, Ulick S, Cook S, Wang JZ, Lifton RP, Dluhy RG: Glucocorticoid-remediable aldosteronism in a large kindred: clinical spectrum and diagnosis using a characteristic biochemical phenotype. Ann Intern Med 1992; 116:813-820

10 Lifton RP, Dluhy RG, Powers M, et al: A chimaeric $11 \beta$-hydroxylase/aldosterone synthase gene causes glucocorticoid-remediable aldosteronism and human hypertension. Nature 1992; 355:262-265.

-11 Mune T, Rogerson FM, Nikkila H, Agarwal AK, White PC: Human hypertension caused by mutations in the kidney isozyme of $11 \beta$-hydroxysteroid dehydrogenase. Nat Genet 1995; 10:394-399.

12 Geller DS, Farhi A, Pinkerton N, et al: Activating mineralocorticoid receptor mutation in hypertension exacerbated by pregnancy. Science 2000;289:119-123.

13 Dahl LK, Heine M: Primary role of renal homografts in setting chronic blood pressure levels in rats. Circ Res 1975;36:692-696.

14 Bianchi G, Baer PG, Fox U, Guidi E: The role of the kidney in the rat with genetic hypertension. Postgrad Med J 1977;53(suppl 2):123138.

15 Curtis JJ, Luke RG, Dustan HP, et al: Remission of essential hypertension after renal transplantation. N Engl J Med 1983;309:10091015.
16 De Wardener HE, MacGregor GA: The natriuretic hormone and hypertension. Contrib Nephrol. Basel, Karger, 1980, vol 21, pp 8187.

17 Levy D, DeStefano AL, Larson MG, et al: Evidence for a gene influencing blood pressure on chromosome 17: Genome scan linkage results for longitudinal blood pressure phenotypes in subjects from the Framingham Heart Study. Hypertension 2000;36:477-483.

18 Hilbert P, Lindpaintner K, Beckmann JS, et al: Chromosomal mapping of two genetic loci associated with blood-pressure regulation in hereditary hypertensive rats. Nature 1991;353: 521-529.

19 Jacob HJ, Lindpaintner K, Lincoln SE, et al: Genetic mapping of a gene causing hypertension in the stroke-prone spontaneously hypertensive rat. Cell 1991;67:213-224.

20 Sugiyama F, Churchill GA, Li R, et al: QTL associated with blood pressure, heart rate, and heart weight in $\mathrm{CBA} / \mathrm{CaJ}$ and $\mathrm{BALB} / \mathrm{cJ}$ mice. Physiol Genomics 2002;10:5-12.

21 Law CM, Shiell AW: Is blood pressure inversely related to birth weight? The strength of evidence from a systematic review of the literature. J Hypertens 1996;14:935-941.

22 Law CM, Martyn CN, Fall CH, Osmond C: Raised adult blood pressure linked to failure to achieve growth potential in utero. BMJ 1996; 312:1479.

23 Yiu V, Buka S, Zurakowski D, McCormick M, Brenner B, Jabs K: Relationship between birthweight and blood pressure in childhood. Am J Kidney Dis 1999;33:253-260.

24 Manning J, Vehaskari VM: Low birth weightassociated adult hypertension in the rat. Pediatr Nephrol 2001;16:417-422.

25 Flack JM, Ferdinand KC, Nasser SA: Epidemiology of hypertension and cardiovascular disease in African Americans. J Clin Hypertens (Greenwich) 2003;5:5-11.

26 Hajjar I, Kotchen TA: Trends in prevalence, awareness, treatment, and control of hypertension in the United States, 1988-2000. JAMA 2003;290:199-206.

27 Fuller KE: Low birth-weight infants: The continuing ethnic disparity and the interaction of biology and environment. Ethn Dis 2000;10: 432-445.

28 Merlet-Benichou C, Gilbert T, Muffat-Joly M, Lelievre-Pegorier M, Leroy B: Intrauterine growth retardation leads to a permanent nephron deficit in the rat. Pediatr Nephrol 1994;8: 175-180.

29 Manning J, Beutler K, Knepper MA, Vehaskari VM: Upregulation of renal BSC1 and TSC in prenatally programmed hypertension. Am J Physiol Renal Physiol 2002;283:F202-F206.
30 Hansson JH, Schild L, Lu Y, et al: A de novo missense mutation of the $\beta$ subunit of the epithelial sodium channel causes hypertension and Liddle syndrome, identifying a prolinerich segment critical for regulation of channel activity. Proc Natl Acad Sci USA 1995;92: 11495-11499.

31 Hansson JH, Nelson-Williams C, Suzuki H, et al: Hypertension caused by a truncated epithelial sodium channel $\gamma$ subunit: Genetic heterogeneity of Liddle syndrome. Nat Genet 1995; 11:76-82.

32 Shimkets RA, Lifton RP, Canessa CM: The activity of the epithelial sodium channel is regulated by clathrin-mediated endocytosis. J Biol Chem 1997;272:25537-25541.

33 Henry PC, Kanelis V, O'Brien MC, et al: Affinity and specificity of interactions between Nedd4 isoforms and the epithelial $\mathrm{Na}^{+}$channel. J Biol Chem 2003;278:20019-20028.

- 34 Schild L, Lu Y, Gautschi I, Schneeberger E, Lifton RP, Rossier BC: Identification of a PY motif in the epithelial $\mathrm{Na}$ channel subunits as a target sequence for mutations causing channel activation found in Liddle syndrome. EMBO J 1996;15:2381-2387.

35 Mansfield TA, Simon DB, Farfel Z, et al: Multilocus linkage of familial hyperkalaemia and hypertension, pseudohypoaldosteronism type II, to chromosomes 1q31-42 and 17p11-q21. Nat Genet 1997;16:202-205.

36 Disse-Nicodeme S, Achard JM, Potier J, et al: Familial hyperkalemic hypertension (Gordon syndrome): Evidence for phenotypic variability in a study of seven families. Adv Nephrol Necker Hosp 2001;31:55-68.

37 Wilson FH, Disse-Nicodeme S, Choate KA, et al: Human hypertension caused by mutations in WNK kinases. Science 2001;293:11071112.

- 38 Tripodi G, Valtorta F, Torielli L, et al: Hypertension-associated point mutations in the adducin $\alpha$ and $\beta$ subunits affect actin cytoskeleton and ion transport. J Clin Invest 1996;97: 2815-2822.

- 39 Grant FD, Romero JR, Jeunemaitre X, et al: Low-renin hypertension, altered sodium homeostasis, and an $\alpha$-adducin polymorphism. Hypertension 2002;39:191-196.

-40 Barkalow KL, Italiano JE Jr, Chou DE, Matsuoka Y, Bennett V, Hartwig JH: $\alpha$-Adducin dissociates from $\mathrm{F}$-actin and spectrin during platelet activation. J Cell Biol 2003;161:557570.

41 Guyton AC: Kidneys and fluids in pressure regulation. Small volume but large pressure changes. Hypertension 1992;19(suppl):12-18.

42 Guyton AC: Blood pressure control - Special role of the kidneys and body fluids. Science 1991;252:1813-1816.

-43 Johnson RJ, Herrera-Acosta J, Schreiner GF, Rodriguez-Iturbe B: Subtle acquired renal injury as a mechanism of salt-sensitive hypertension. N Engl J Med 2002;346:913-923. 
-44 Brenner BM, Garcia DL, Anderson S: Glomeruli and blood pressure. Less of one, more the other? Am J Hypertens 1988; 1:335-347.

$\checkmark 45$ Guyton AC, Coleman TG, Cowley AV Jr, Scheel KW, Manning RD Jr, Norman RA Jr: Arterial pressure regulation. Overriding dominance of the kidneys in long-term regulation and in hypertension. Am J Med 1972;52:584594.

-46 Mailloux LU, Haley WE: Hypertension in the ESRD patient: Pathophysiology, therapy, outcomes, and future directions. Am J Kidney Dis 1998;32:705-719.

47 Charra B, Calemard M, Laurent G: Importance of treatment time and blood pressure control in achieving long-term survival on dialysis. Am J Nephrol 1996;16:35-44.

48 Charra B, Bergstrom J, Scribner BH: Blood pressure control in dialysis patients: Importance of the lag phenomenon. Am J Kidney Dis 1998;32:720-724.
49 Keller G, Zimmer G, Mall G, Ritz E, Amann $\mathrm{K}$ : Nephron number in patients with primary hypertension. N Engl J Med 2003;348:101108.

50 Woods LL: Fetal origins of adult hypertension: A renal mechanism? Curr Opin Nephrol Hypertens 2000;9:419-425.

51 Woods LL, Weeks D, Rasch R: Hypertension after neonatal uninephrectomy in rats precedes glomerular damage. Hypertension 2001;38: 337-342.

52 Moritz KM, Wintour EM, Dodic M: Fetal uninephrectomy leads to postnatal hypertension and compromised renal function. Hypertension 2002;39:1071-1076.

53 Baudoin P, Provoost AP, Molenaar JC: Renal function up to 50 years after unilateral nephrectomy in childhood. Am J Kidney Dis 1993;21:603-611.
54 Provoost AP, Brenner BM: Long-term followup of humans with single kidneys: the need for longitudinal studies to assess true changes in renal function. Curr Opin Nephrol Hypertens 1993;2:521-526.

55 El Kahder K, Guille F, Patard JJ, et al: Ureteral reimplantation on psoas bladder: longterm results (in French). Acta Urol Belg 1998; 66:15-20.

56 Bock HA, Bachofen M, Landmann J, Thiel G: Glomerular hyperfiltration after unilateral nephrectomy in living kidney donors. Transpl Int 1992;5:S156-S159.

57 Fehrman-Ekholm I, Duner F, Brink B, Tyden G, Elinder CG: No evidence of accelerated loss of kidney function in living kidney donors: results from a cross-sectional follow-up. Transplantation 2001;72:444-449.

58 Fehrman-Ekholm I, Brink B, Ericsson C, Elinder CG, Duner F, Lundgren G: Kidney donors don't regret: follow-up of 370 donors in Stockholm since 1964. Transplantation 2000; 69:2067-2071 